La

Révolution

française

\section{La Révolution française}

Cahiers de l'Institut d'histoire de la Révolution française

$20 \mid 2021$

La Révolution en 3D - Textes, images, sons

(1787-2440)

\title{
"To the United States of France and Ireland": revolutionary circulations between France and Ireland during the Age of the Atlantic Republic
}

\section{Mathieu Ferradou}

\section{(2) OpenEdition}

\section{Journals}

Electronic version

URL: https://journals.openedition.org/lrf/4920

DOI: $10.4000 /$ Irf.4920

ISSN: 2105-2557

Publisher

IHMC - Institut d'histoire moderne et contemporaine (UMR 8066)

Electronic reference

Mathieu Ferradou, "'To the United States of France and Ireland": revolutionary circulations between France and Ireland during the Age of the Atlantic Republic ", La Révolution française [Online], 20 | 2021, Online since 25 June 2021, connection on 28 June 2021. URL: http://journals.openedition.org/lrf/4920 ; DOI: https://doi.org/10.4000/Irf.4920

This text was automatically generated on 28 June 2021.

(c) La Révolution française 


\title{
"To the United States of France and Ireland": revolutionary circulations between France and Ireland during the Age of the Atlantic Republic
}

\author{
Mathieu Ferradou
}

\section{EDITOR'S NOTE}

$\mathrm{PhD}$ thesis defended on 26th of November 2019 before a jury composed of Clément Thibaud (Professor, EHESS), president; Céline Borello (Professor, Le Mans university, TEMOS), recorder; Philippe Bourdin (Professor, Blaise Pascal University, ClermontFerrand, $\mathrm{CEHC}$ ), recorder; Thomas Bartlett (Emeritus Professor, University of Aberdeen, Royal Irish Academy); Pierre Serna (Professor, University of Paris 1 PanthéonSorbonne), thesis director.

\section{AUTHOR'S NOTE}

My heartfelt gratitude goes to Tim Murtagh for his reading and comments on the first version of this text in its English version.

'Now you A.B. voluntarily declare to be true to the present United States of France and Ireland and of every combined kingdom state in Christianity that is now or hereafter may be for the welfare of our United Brethern ; that you aid them as far as in your power lies without hurting your soul or body as long as they to you prove loyal.' 
1 The term 'United States of France and Ireland' can be found on numerous oaths, catechisms and posters, both handwritten and printed, in Ireland in 1795-6, as exemplified with the quoted oath above, written on a small paper, and found in June 1795 by Barry Maxwell, $1^{\text {st }}$ Earl Farnham, in the streets of Cavan (Co. Cavan) in Ulster. Farnham sent it promptly to the Castle in Dublin, seat of the Anglo-Irish government, where Lord Lieutenant Camden compiled it with other documents on the secret society of the Defenders, in order to prepare a digest for the Home Office in London. ${ }^{1}$

2 The society of the Defenders, which first appeared in the 1780s in Co. Armagh, was a source of anxiety for the governments both in Dublin and London since the early 1790s. The Castle agents tried to obtain precise and reliable information on this secret society, whose members were mainly Catholics but who were then operating a fusion with the society of the United Irishmen. This development constituted a very worrying prospect for the Castle as the latter were founded in November 1791 in Belfast and Dublin by Protestants, mainly Ulster Presbyterians, and had become, in the prevalent narrative, revolutionaries since 1794. This alliance of the discontents of Ireland, Catholics and Protestants, against the domination of England was a source of fear, particularly for the so-called 'Ascendancy' - the Protestant elite of about 5,000 landowners, descendants of the English colonists who considered the government of Ireland to be their possession. The reference to France in these oaths and catechisms sent shivers of panic : the fear of a French invasion of Ireland, transforming the island into a beachhead from where to launch an attack against England, was a recurring nightmare since the beginning of the 'Second Hundred Years War' (1688-1815) between France and England.

3 This nightmare was on the verge of becoming a reality in December 1796-January 1797, when General Lazare Hoche led a formidable French-Irish expedition which was meant to land in the south of the island. The breakaway of the ships as soon as they left the safety of Brest and the tempest which further dispersed the fleet prevented the landing, in what was perhaps the moment with the highest potential of counterfactual history - Ireland was not invaded. The four expeditions sent during the summer of 1798 , after the news of the insurrection of the Irish had reached France, came too late : the insurgents had already been crushed both in the south around Wexford and in the north, and, despite some initial successes leading up to the short-lived Republic of Connaught, the French armies were defeated, on land as well as on sea. The repression of this ‘Great Rebellion' provoked perhaps 30,000 dead and deeply traumatized the Irish memory which, in turn, saturated the historiography about the period.

4 In the prevalent historiography in English - not to mention the almost non-existent historiography in French for the last century - dealing with the links between revolutionary France and 'rebellionist' Ireland, the Defenders are presented as depending upon the United Irishmen to receive the revolutionary dynamics that France then embodied. ${ }^{2}$ The discontentment of the Defenders was supposedly conservative, parochial ; and they have been pictured as clinging superstitiously to their religious Catholic identity and to cultural traditions that were the hallmarks of a vanished, ahistorical world. The Defenders were, in this sense, not a part of history. The predecessors of the Defenders, the Whiteboys of Munster, who protested against the enclosures, claiming their loyalty to both King Georges and Queen Sive (Sadhbh), a fairy queen from Irish myths, have been characterized by Sean Connolly as "conservative and defensive, concerned to fend off unwelcome change rather than to challenge the social or political order'. ${ }^{3}$ According to Marianne Elliott, whose work on the links between 
France and Ireland in the 1790s was seminal, the Defenders, shaped by the representations of a popular world of rural protest, tied with Jacobitism, were fossilised in a mythicized past, finding refuge in the nostalgic folklore of a vanished world. The passage from a 'depoliticised Catholicism' to a 'nationalist Catholicism' in the 1790s could then only be explained by the prevalent influence of the propaganda of the United Irishmen who were, contrary to their allies, heirs to the Enlightenment and inserted in the revolutionary flows crossing the Atlantic during the Age of Revolutions. Even the references to France in the Defenders' oaths as soon as 1792 (hence before the United Irishmen whose alliance with France was formally concluded in 1796) are interpretated by Marianne Elliott as cosmetic. In this view, the Defenders were able neither to grasp the stakes nor to understand the political implications of the references they used. ${ }^{4}$ According to Elliot, the United Irishmen played with fire when they allied themselves with the Defenders, the latter being unable to integrate the enlightened and secularised republicanism of their Protestant allies. Defenderism, she writes, corrupted Irish republicanism since its inception, warping it into a Catholic, fanatical, and exclusive nationalism. ${ }^{5}$ Nancy Curtin wrote that 'both allies [France and the Defenders] were necessary to make the United Irishmen a formidable revolutionary organization, but, taken together, these alliances contributed to [...] an ugly explosion of sectarian hostility in Ireland'. ${ }^{6}$ Even Jim Smyth concluded his study on popular politicisation in Ireland by reasserting that 'a tension did exist between Defender sectarianism and the urbane secular republicanism of the United Irish leadership', the 'gut Catholic nationalism' remaining 'the central dilemma of modern Irish republicanism'.

5 This revisionist historiography has been challenged by several historians, sometimes dubbed 'post-revisionist' century were grafted onto the international currents. The 'rebellionist' movements associated a hostility toward the Hanoverian state perceived as foreign, with an opposition to the economic transformations provoked by the mercantile and slavebased Atlantic capitalism that disbarred them of their traditional rights. This association was made through the vector of their political and religious culture. Their exaltation of a vanished social order was not, in this sense, synonymous with a lack of connection with their own times but, quite the contrary, a testament to their ability to use other political languages to propose an egalitarian political and social alternative (the Irish sept or clan in which lands were held in common). .9 This reassessment had not, up until now, included the revolutionary period and the prevalent historiography considered the United Irishmen to be ambiguous republicans and reluctant revolutionaries who only renounced to their deeply held constitutionalism when faced with the repression led by Dublin Castle from 1794. As for the Defenders, they are still mainly considered as inept or hypocritical republicans, moved only by their fanaticism and their anti-protestant hatred. Irish republicanism can only be understood, in this light, as a thin layer on an atavistic nationalism, which had donned the different faces of discontentment available at different moments (Jacobite and then Jacobine) but never really changing its fundamental nature. ${ }^{10}$

6 This debate is not only relevant for the late eighteenth century and early nineteenth century but also touches on the historiography dealing with the long nineteenth Irish century, opened with the French Revolution and closed with the Irish revolutionary decade from 1913 to 1923: Irish republicanism would be synonymous with Catholic nationalism expressed through violence and refusing constitutionalism and democracy, 
which were perceived as English imports. ${ }^{11}$ Of course, all these debates are haunted by the spectre of the armed struggle that the IRA and then the 'Real IRA' have embodied during the 'Troubles' from 1969 to $1998 . .^{12}$ The start of the 'Troubles' in Northern Ireland coincided with the liberal turn in globalisation in the 1970s, generating a triumphant revisionism in a common dynamic in post-1968 France and post-1969 Ireland, condemning the Irish republican irredentism and the Revolution in France. In both countries, what was at stake was a liberal conception against a democratic conception of the 'Republic'. In the liberal vision, the popular classes were seen as playing a negative role, contaminating the gestating representative democracy with their popular passions. ${ }^{13}$

7 This dissertation, conducted in the immediate follow-up of a Master 2 in 2013-2014 ${ }^{14}$ and of the international workshop which took place at the IHRF in $2016^{15}$, enters the historiographic fray, dealing also with the public uses of history. Conceived as a study of the politicisation of the popular classes in Ireland, it was also meant to sidestep the historiographical deadlock that was reached in 1998 during the Bicentenary of the Rising. The aim was to refocus these debates on the nature of the republic in the context of the Age of Revolutions, two fields that were profoundly renewed during the last 30 years or so. ${ }^{16}$ While Marianne Elliot's seminal book, Partners in Revolution, constituted the very groundwork upon which this dissertation was based, the ambition was to propose a history 'from below' and closer to the sources.

8 Twenty-eight Irishmen and women constituted the central object of this study. All of them were in Paris in 1792 when France became a republic. At different points they all acted as go-between, mediators and even interfaces between France and Ireland but also between social classes. Studying the revolutionary circulations between these two countries concretely entailed a step-by-step reconstruction of European and Atlantic circulations of these mediators of cultural and political transfers between Ireland, France, England, Scotland, Germany, the United Provinces/ Batavian Republic and the United States. More than that, the implication of many of these 'protagonists', who were indeed swept over by the revolutionary maelstrom, in spying activities had generated many fantasies and unproved allegations, repeated over and over from books to books. A patient reading and identification of coded or partially erased sources, most often than not anonymous, in a classic positivist epistemology but also inspired by the paradigm of evidence as defined by Carlo Ginzburg, was necessary when facing the existence at the same time and sometimes in the same place of three different Nicholas Madgetts, three Ferrisses, two Ducketts, five MacMahons and two MacSheehys (and all of whom had their names spelled differently). New sources previously unknown have been identified in this way, shedding new light on several aspects.

9 The methodological approach was influenced by network studies : a deep dig into the archives (about 60,000 pages of documents in 500 cartons found in archival repositories in France, England and Ireland, produced by governments that employed or watched against these 'vagabonds of the Republic' ${ }^{17}$ ) was necessary to reconstruct the itineraries of these Irish patriots and, more importantly, the relations they built. Their actions were extracted from the sources, linking different actors. Overall, 5,000 actions, involving 1,280 actors (among them were 900 individual actors, 203 collective actors and 140 cultural 'actors') were implemented into a database, based on the Fichoz system developed by Jean-Pierre Dedieu. ${ }^{18}$ At the center of these almost 1,300 actors 
were the twenty-eight Irishmen and women who articulated different networks, linking them together, forming networks of networks. This web of relationships, patiently reconstructed (and yet still and necessarily incomplete) and mapped (with the software Pajek), gives a glimpse, from a French-Irish point of view, of the 'Atlantic Republic' between 1792 and 1798.

My ambition, with this $\mathrm{PhD}$, was indeed to further explore and even to contribute to the definition of this concept, first proposed by Pierre Serna. ${ }^{19}$ The aim was not to study the 'influence' of the French Revolution in Ireland in an unsatisfying diffusionist model but rather to comprehend how these reconstructed revolutionary circulations constituted evidence of a revolutionary or, more specifically and more accurately, republican synergy. ${ }^{20}$ Whereas Ireland is often reduced to a mere footnote in the literature about the revolutionary Atlantic, especially in the French historiography, the thesis proposed here is that, to the contrary, Ireland constituted a laboratory, because of its colonial situation, where a theory of national independence and a praxis of clandestine and armed struggle was invented through a process of crystallisation of different political and insurrectional traditions, the sum of which can be called the 'republic', and more specifically a 'republic at $\mathrm{arms}^{21}$. The process of connection between the protagonists and the actors is therefore a synchronisation which brings them all into the same regime of historicity, one characterised by the horizon of expectation that they try to bring forth, i.e. the 'Republic of the United States of France and Ireland', and a synchorisation, i.e., a linking or 'co-spatiality' of the Atlantic spaces through a transnational synergy, as the Defender oath attest, with the three centres of the United States, France and Ireland. ${ }^{22}$

The dissertation focuses on the precise moment when this double movement of synchronisation and synchorisation was perceptible, from the founding of the republic in France in 1792 to the Irish rising of 1798 when a republic failed to be established. Structured in three chronological parts, in a diachronic approach, attentive to the ruptures and continuities, its aim is to propose a renewed narrative of the transformative years which had seen a failed attempt at establishing a republic in Ireland which would have been integrated, perhaps more significantly, in an Atlantic republican federation. It is therefore the story of a possible outcome which did not come to be, and because it failed, it was necessary to remove the numerous historiographical screens, which were themselves determined by the memorial screens, that came out of this failure, creating a mythistory. ${ }^{23}$

The first part starts with the key-moment when France became a republic, between August 1792 and February 1793, an event that triggered immediate reactions throughout the anglophone and Atlantic worlds, especially among English, American, Scottish and also, perhaps first and foremost, Irish patriots. The Revolution of 1789 had already been identified by Theobald Wolfe Tone as 'that morning star of liberty to Ireland', because it was a demonstration that the French, being Catholics, were also capaces libertatis, contrary to deeply-held beliefs by Protestants and whigs. ${ }^{24}$ The founding of the republic confirmed that France was rejoining the republican family, which raised an immense hope in Ireland, and drew many Irishmen and women to Paris, to 'be there', thereby participating in that revolutionary event or, being already there (as were the Irish students at the Irish College in Paris), were drawn into the revolutionary enthusiasm. Two events were scrutinized in this respect. The first was the 'Republic at the College' when, on 29 October 1792, the students, led by William 
Duckett, took control of the Irish College in Paris, profiting from the absence of the superiors of the college whom they accused of being counter-revolutionaries. They organised an election there with the help of the Paris Commune, transforming this place into a micro-republic and grafting it onto the Republic that was founded in France, thereby saving the college from the threat of being doubly considered as foreigner (as Irish and, more importantly, as counter-revolutionary) by the sansculottes of the faubourg Saint-Marcel. The second event was the 'patriotic feast' at White's Hotel on 18 November 1792, when a hundred or so 'convives' (guests), from throughout the whole Atlantic revolutionary galaxy, gathered around Thomas Paine to celebrate the recent French military victories of Valmy and Jemappes, founding in so doing the society of the English, Scottish and Irish at Paris, later known as the Société des Amis des Droits de l'Homme (Society of the Friends of the Rights of Man) or SADH, improperly known as the 'British Club' in the prevalent historiography. One third of the 50 signatories of the address of congratulations to the French Convention, which came out of this dinner, were Irish. This festive, joyous, and probably even raucous moment constitutes a window of observation into the transatlantic republicanism that expressed itself through the toasts and numerous reviews of the event in the press on both sides of the Channel. These two events were linked by their protagonists, who were involved in a conspiracy, led by Thomas Paine and Edward FitzGerald, to revolutionise and republicanise Ireland, which appeared, as Paine himself wrote, as 'the most interesting theatre where the whole play shall be staged'. ${ }^{25}$ Placing the diner at White's in the context of the rising of the tensions between France and England sheds light on this event as a public occasion hiding in plain sight the hidden activities of the SADH. The conspiracists were trying to obtain the commitment of the French government towards Ireland in this project of the republicanisation of the 'Three Kingdoms' by placing them before the fait accompli. In this light, it is possible to interpret the (in)famous decree of 19 November promising 'help and relief to all peoples striving to recover their liberty' as a response to the diner which took place the day before, and, in a broader context, as the participation of France in a trans-Channel dialogue which began with the start of the Revolution. ${ }^{26}$ The English government, closely scrutinizing these developments, reacted swiftly and intelligently, with a series of measures, balancing concessions (by giving to Irish Catholics the right to vote) with harsh repression, preventing this insurrectionary project. It appears that the Irish in Paris played a decisive part in the rising of the hostilities between France and England, and that it was not the declaration of war of February 1793 which renewed the connection that existed between France and Ireland since Louis XIV, but rather it is the connection between Irish, English, Scottish, American, and French republicans in a project of republicanisation of Ireland, then Scotland and, finally, England, which provoked the war.

13 The second part of the dissertation follows the continuities between 1792 and 1796. The connections that were established during the key-moment of 1792 were put to much use, in the context of the war, to establish a republic in Ireland. The context was also one of ideological change : the transition from a Girondin to a Montagnard Convention was not, however, synonymous with a rupture, contrary to the prevalent narrative (which is more prevalent in media than in academia) about the treatment of foreigners in France. Political orthodoxy narrowed down in the context of the state of siege that France was going through, but Irishmen and women managed to be recognized as brothers in a struggle for liberty and independence by the French authorities. ${ }^{27}$ The 
hypothesis defended here is that the Girondin cosmopolitanism did not give way to a Montagnard nationalism or xenophobia, but was rather replaced by a republican internationalism defined by reciprocity. It is within this internationalist framework that the French-Irish missions of the years 1793-6 were reexamined. The numerous obstacles that the initiators of these missions (Eleazer Oswald, Richard Ferris, and Eugene Aherne) met, their brutal end or apparent failure, must not lead to erroneous conclusions : far from being merely disorganised and unfocused propaganda, which produced few, if any, results, they now appear as essential stepping stones in a negotiation, rendered extremely difficult by the war, between the French government and the Irish republicans. Propaganda, coordination, spying, and infiltration of the English government - these missions were indeed a continuous link between France and the Irish, Scottish and even English republicans. The Duckett mission, and more particularly, the 'Junius Redivivus' letters that he published in the Morning Chronicle in 1794 are here extensively analysed for the first time. First initiated by personal impetus, these missions were progressively organised and centralised by the bureau des traductions, led by the ex-priest Nicholas Madgett, and directly attached to the Committee of Public Safety. The key-role of these missions did not escape the intelligence of the English government, and the William Jackson mission, named after the clergyman and journalist who was sent to England and Ireland at the beginning of 1794 to gauge the possibility of an invasion in both countries, provoked a backlash from the English government in the form of the first wave of arrests and treason trials against the popular societies in both countries in 1794-1795.

The third part of the dissertation continues to follow up the thread of the connections between France and Ireland until the expeditions of Bantry and even until 1798. The circulations of memoirs and of key cultural intermediaries, the central role of Madgett and of his bureau des traductions in the transition between the Committee of Public Safety and the Directory, the Irish actors who were part of General Hoche's entourage and who succeeded in convincing France to truly commit itself in favour of Ireland's independence are all reexamined. Theobald Wolfe Tone's central role as 'ambassadeur incognito' of the United Irishmen to the French government is nuanced and perhaps minimised in the light of the remarkable continuity of the Irish network lobbying the government in Paris since 1792 in direct contact with Ireland and the United States. The failure of the Bantry Bay expedition is a first setback, but less grievous than the crisis of 1797 with the death of General Hoche and the internal crisis within the Directory during the summer (which produced the eviction of Foreign Minister Delacroix and his replacement by Talleyrand). The true break occurred with this crisis : the Irish networks were almost completely disrupted and had to be reconstructed almost from scratch (most notably from the Ministry of Marine) and they never recovered the same influence. At the same time, and perhaps as a consequence, being now marginalised in Paris, the Irish turned toward the ocean and the Atlantic Republic, in its Irish component, then became the Republican Atlantic, the 'floating Republic' or the 'maritime Republic' of the mutinies in the English Navy, of the ports, and ships of all the Atlantic seaboard from Brest to Hamburg. ${ }^{28}$ Here, the connections are much more difficult to retrace. William Duckett seems, again, central : crossing tirelessly this space, between Brest, Paris, Hamburg, London, and Ireland, he seems to be at the crossroads of these connections. His presence at the side of Léonard Bourdon in Hamburg at the end of 1797 and early 1798, his attempt, with him, to recreate the 'spirit of 92' by organising a 'fraternal banquet', his contact with Catholic priest James 
Coigly, the impetus behind the founding of the United Englishmen and United Scotsmen, tied up with the United Irishmen now allied with the Defenders, in a renewed project of a insurrection in the Three Kingdoms, the flurry of activity surrounding Arthur O'Connor and Edward FitzGerald at the same time - all these signs point to a concrete project of founding three distinct republics united in a federation with France which would then extend to all Europe. Again, these underground circulations were closely watched by the English government which deployed all its resources to destroy it before it could hatch: the new wave of repression in February and March 1798 was accompanied by a very powerful counterrevolutionary discourse, particularly through the treason trials and iconic caricatures. The Atlantic seditious republicans were presented as atheist, blood-drinking conspiracists, pre-figuring how the events of 1798 would be perceived and read, creating a pre-memory of the Rebellion..$^{29}$ When the insurrection finally broke out in Ireland, it was more from despair on the part of the United Irishmen/ Defenders who were backed into a corner by the campaign of methodical repression. Despite initial successes, the lack of French backing at this precise moment condemned the insurgents in the short run. The broken fates of the 28 Irishmen and women who were the focus of the dissertation constitutes the tragic epilogue, examining the question of living after, or dying during, the failed revolution.

From this study of these six crucial years emerges a picture of the Atlantic Republic:

Fig. 1: The Atlantic Republic of the United States of France and Ireland: the network of the 28 Irishmen and women, 1792-8.

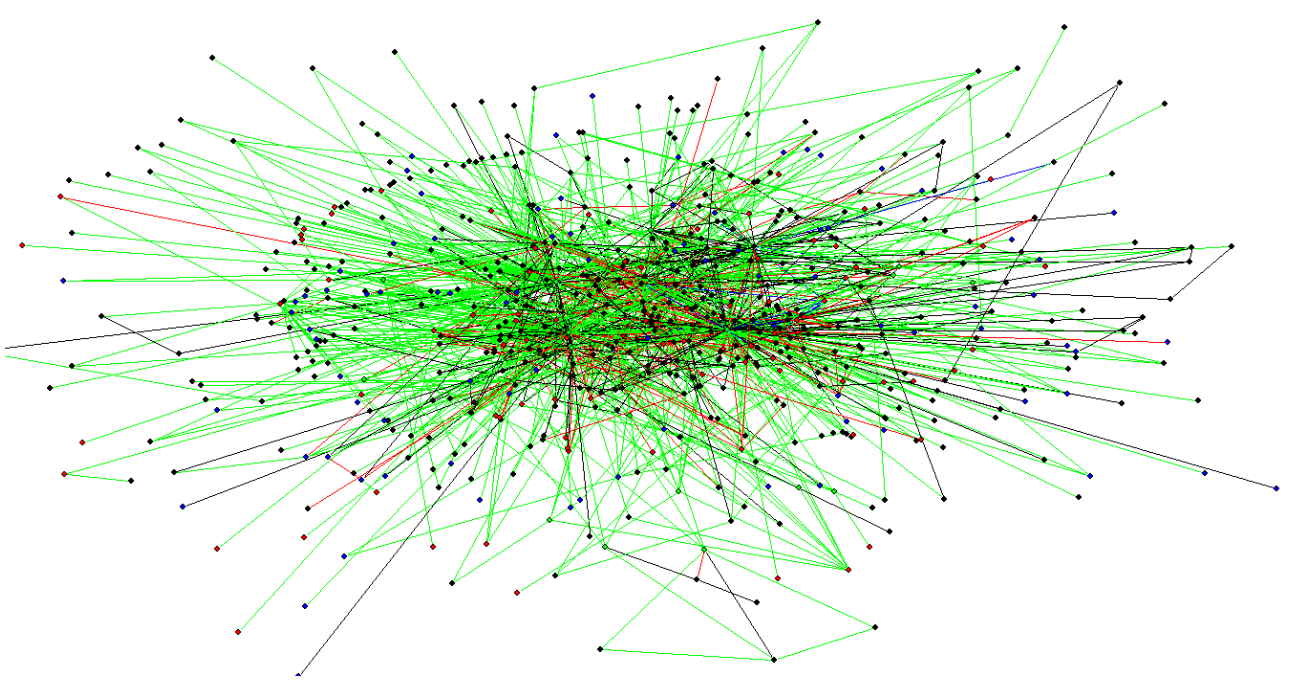


Fig. 2 : The Atlantic Republic of the United States of France and Ireland, 1792-8. Vectorised map.

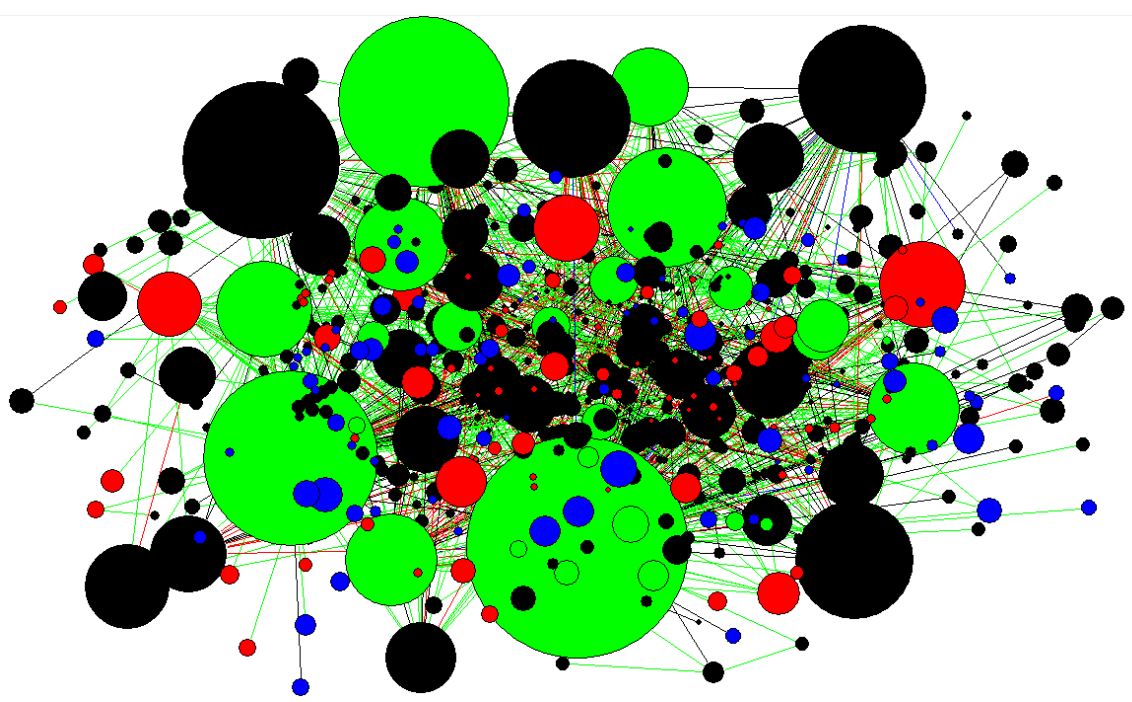

Reading notes: The 28 Irishmen and women are shown in green, the other individual actors are in black, the collective actors in red and the cultural 'actors' in blue.

Links in black indicate neutral actions, in green friendly actions, in red hostile actions.

The size of circles depends on the frequency of the actor's mentions in the sources. It must not be taken too literally, as it is largely the product of an 'effet de source'. More telling is the position of each actor relative to the others, which also depends on the number of actions that link them.

Interpretating these maps is somehow tricky. Yet, perhaps the greatest lessons they impart is the 'strength of weak links' (apparently marginal actors may have a very important role in connecting two distinct networks), and the places where antagonist networks are linked (see below for an example).

These images show that the actors who have been studied in this PhD have linked, through their socio-spatial practices, the palaces of the new republican institutions in Paris with the Irish rural areas, agitated with discontentment; the taverns in Paris, Dublin, London with the headquarters of the French generals; the ports from Brest to Hamburg. In between all these places, they circulated and brought with them newspapers (in which they published papers), memoirs, letters : this circulation of men and women is also a circulation and a translation (including in its Latin sense). It therefore defined the ideological, political and mental framework of the struggle for independence in Ireland. As such, far from being isolated and secluded in their backwater Irish counties, the Defenders were directly connected, as soon as 1792, with the revolutionary and republican currents. The most striking image to show the implications of these flows is perhaps the one of the 'fraternal banquet' in Hamburg in the spring of 1798 when Duckett arranged for Defender leaders, agents of the French government and representatives of the German Enlightenment to seat at the same table and sing the same songs. 
Fig. 3 : Vectorised map of the network of the Atlantic Republic, June 1796-December 1799.

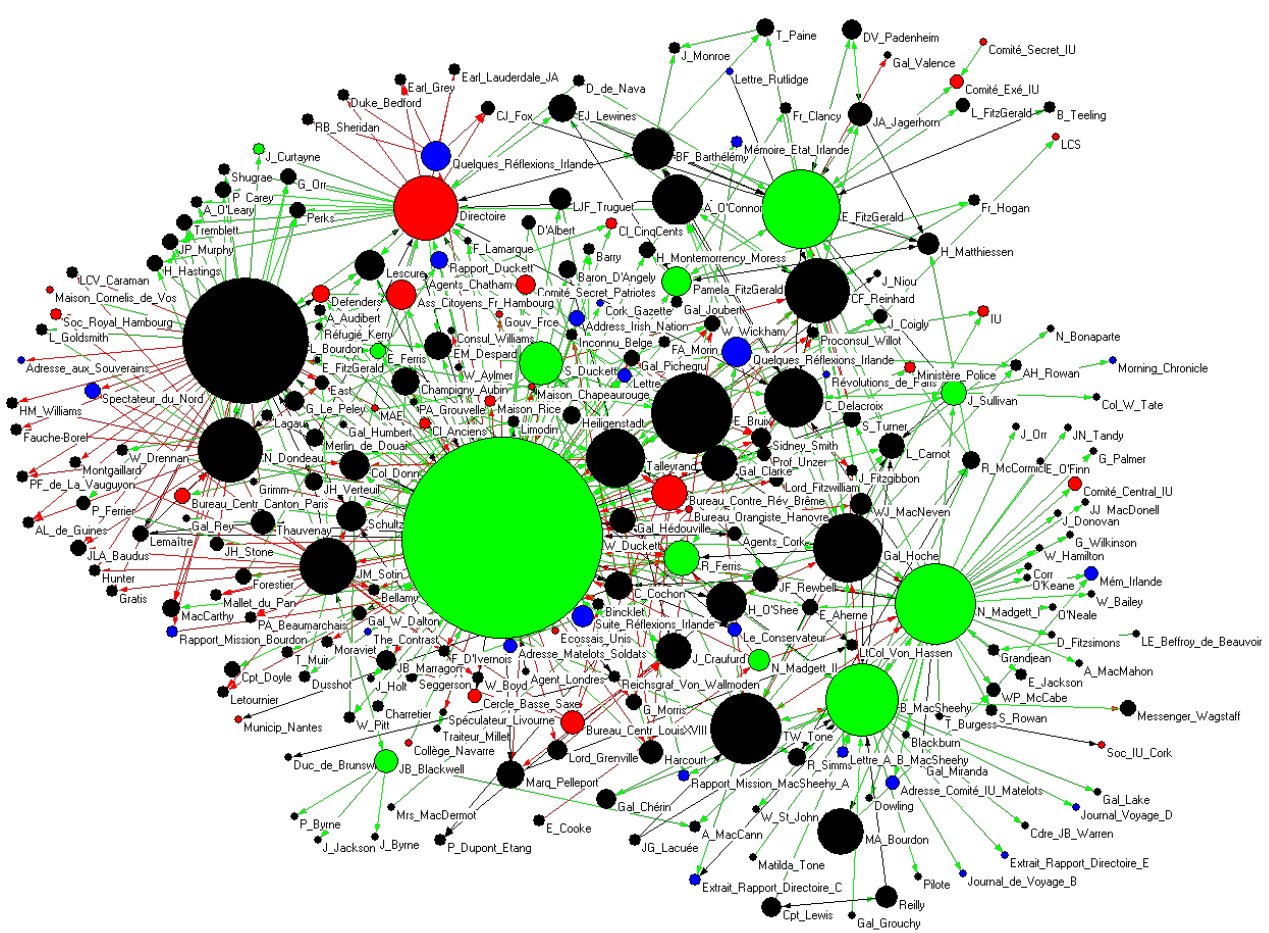

Reading note: We can see here the centrality of Duckett (the green circle in the centre), his proximity with Leonard Bourdon (the black circle to the left) and the minister of Marine Bruix and how they connected the revolutionary networks with the counter-revolutionary ones (the red lines to the left), having been spotted by the latter.

The prevalent narrative about the United Irishmen can now be revised in the light of this broader focus. As soon as November 1792, several future leaders of the society were present at White's (Edward FitzGerald, the Sheares brothers, Duckett, Madgett) or in contact with Paine (Archibald Hamilton Rowan) and, in the context of the founding of the republic in France, they conspired to do the same in Ireland. This original core was then revived several times, first with the French-Irish missions, then through the 'diplomacy' of the United Irishmen to the Directory, from 1792 to 1798 , in a remarkable continuity and adaptability despite the great upheavals of the period. The break of 1794, the one which would see the United Irishmen transform from constitutionalist reformers to separatist revolutionaries, now appears to make sense only in the Irish context : replaced in the context of transnational circulations, the Irish patriots were already republican and revolutionary, something that the English government understood perfectly, identifying the threat they posed and doing all it could to prevent them, at three crucial moments, to establish a republic in Ireland.

The story of the Irish republic that did not come to be makes sense when it is analysed in its transnational, Atlantic context : it is possible to assert that the Republic was the horizon of expectancy for all these actors and it was the name of a true heterotopia, a diffracted space whose central places were taverns, these places of interclass sociability, where Irishmen and women imagined another world. ${ }^{30}$ Writing the history of this failure necessitates to leave mythistory which has been relegating their vision to a damnatio memoriae, as much forgetting as condemnation, directly borne out of the English counterrevolutionary discourse, and placing Ireland back at the centre of the 
dynamics of the Atlantic Republic, as a laboratory where the definition of the democratic republic was reinvented.

\section{NOTES}

1. The draft of the digest (in which the word 'kingdom' is significantly crossed and replaced by 'state' is available at the National Archives of Ireland (Rebellion Papers 620/22/19) and the final report are at the National Archives, Kew (Home Office 100/ 58 ff 178-210, 345-350). They have been published by Thomas BARTLETT, 'Defenders and Defenderism in 1795', Irish Historical Studies, vol. 24, n 95, May 1985, p. 373-394.

2. I try here to translate Jean Nicolas's neologism which he used to describe 'rebellionist' France in the $18^{\text {th }}$ century as more and more 'intranquille' (unquiet), which presents remarkable parallels with Ireland at the same period. For a recent review of the historiography, whether in French or in English, see : Mathieu FERRADOU, «Introduction : L'Irlande et la France à l'époque de la République atlantique : historiographie et nouvelles approches ", La Révolution française. Cahiers de l'IHRF [online], $\mathrm{n}^{\circ} 11,2016$, DOI : https://doi.org/10.4000/lrf.1626

3. Sean J. Connolly, 'Eighteenth-century Ireland. Colony or Ancien Régime ?', in David George Boyce and Alan O'Day (ed.), The Making of Modern Irish History. Revisionism and the Revisionist Controversy, London and New York, Routledge, 1996, p. 15-33 (p. 23).

4. Marianne ELliotT, Partners in Revolution. The United Irishmen and France, New Haven \& London, Yale University Press, 1982, p. 16-17.

5. Marianne ELLIOTT, 'The Origins and Transformations of Early Irish Republicanism', International Review of Social History, vol. 23, 1978, p. 405-428.

6. Nancy J. CURTIN, The United Irishmen. Popular Politics in Ulster and Dublin, 1791-1798, Oxford, Clarendon Press, 1998 [1994], p. 65.

7. Jim SмYтH, The Men of No Property. Irish Radicals and Popular Politics in the Late Eighteenth Century, Basingstoke and London, Macmillan, 1992, p. 183.

8. Roy F. FOSTER, Luck \& the Irish. A Brief History of Change since 1970, Oxford, Oxford University Press, 2008, p. 177, dismissed this trend when he wrote that 'post-revisionism amounts to something rather like nationalism with footnotes'.

9. Vincent MORLEY, “'Tá an cruatan ar Sheoirse”: Folklore or Politics?', Eighteenth-Century Ireland / Iris an dá chultúr, vol.13, 1998, p.112-120; ID., 'George III, Queen Sadhbh and the Historians', Eighteenth-Century Ireland / Iris an dá chultúr, vol.17, 2002, p. 112-120; ID., Irish Opinion and the American Revolution, 1760-1783, Cambridge, Cambridge University Press, 2015; The Popular Mind in Eighteenth-Century Ireland, Cork, Cork University Press, 2017. On this idea of the uses of the past as a political reservoir upon which it is possible to theorise discontentment and an alternative order, see Pierre SERNA, «Toute révolution est une guerre d'indépendance », in Jean-Luc CHAPPEY et al, Pour quoi faire la Révolution, Marseille, Agone, 2012, p. 19-49 (English version: 'Every Revolution Is a War of Independence', in Suzanne Desan Lynn Hunt and William Max Nelson (ed.), The French Revolution in Global Perspective, Ithaca \& London, Cornell University Press, 2013, p. 165-182. In this perspective, a remarkable phenomenon and still largely under-researched is the settlement in Ireland of English in the wake of the civil war and the repression of the radical movements, Levellers and Diggers, who converted to Catholicism. The two main protagonists of 
this thesis, William Duckett and Nicholas Madgett, have names that testify to their 'New English' origins and were both Catholics.

10. Sean J. ConNolly, "Jacobites, Whiteboys and Republicans: Varieties of Disaffection in Eighteenth-Century Ireland », Eighteenth-Century Ireland / Iris an dá chultúr, vol. 18, 2003, p. 63-79 ; Hugh GOUGH et Gilles LE BIEZ, «Un républicanisme ambigu : l'Irlande et la Révolution française », Annales historiques de la Révolution française, n² 296, avril-juin 1994, p. 321-330.

11. Sean J. ConNolLy, «The Limits of Democracy: Ireland, 1775-1848 », in Joanna Innes, Mark Philp (ed.), Re-Imagining Democracy in the Age of Revolutions: America, France, Britain, Ireland, 1750-1850, Oxford, Oxford University Press, 2013, p. 174-190; Richard V. COMERFORD, "Republicans and Democracy in Modern Irish Politics ", in Fearghal McGarry (ed.), Republicanism in Modern Ireland, Dublin, University College Dublin Press, 2003, p. 8-22.

12. Thomas BARTLETT, «Avant propos / Foreword: Writing the history of the revolutionary 1790s during the "Troubles": historiographical and moral dilemmas ", La Révolution française. Cahiers de l'IHRF [En ligne], n 11, 2016, DOI : https://doi.org/10.4000/lrf.1624. See also : John REAGAN, » Dr Jekyll and Mr Hyde : 'the Two Histories' ", History Ireland [online], $\mathrm{n}^{\circ}$ 1, January/ February 2012, URL: http://www.historyireland.com/20th-century-contemporary-history/dr-jekyll-and-mrhyde-the-two-histories-2/

13. Fearghal MAC BHLOSCAIDH, « Objective Historians, Irrational Fenians and the Bewildered Herd: Revisionist Myth and the Irish Revolution ", Irish Studies Review, vol. 28, issue 2, 2020, p. 204-234.

14. Mathieu FERRADOU, «Un festin patriotique à l'hôtel White (18 novembre 1792) : les Irlandais patriotes à Paris, 1789-1795 ", mémoire de Master 2 sous la direction de Pierre Serna et avec le soutien de Thomas Bartlett, IHRF, 2014.

15. Mathieu FERRADOU (ed.), L'Irlande et la France à l'époque de la République atlantique, $\mathrm{n}^{\circ}$ spécial de La Révolution française. Cahiers de l'IHRF, $\mathrm{n}^{\circ} 11,2016$.

16. Among the vast literature on the Republic: John G. A. Рососк, The Machiavellian Moment: Florentine Political Thought and the Atlantic Republican Tradition, Princeton, Princeton University Press, 1975; Philip PETTIT, Republicanism. A Theory of Freedom and Government, Oxford, Oxford University Press, 1997; Quentin SKINNER, Liberty Before Liberalism, Cambridge, Cambridge University Press, 1998. On the Atlantic of revolutions : Robert R. PALMER, The Age of Democratic Revolution. A Political History of Europe and America, 1760-1800, Princeton and Oxford, Princeton University Press, 2014 [1959 and 1964]; Jacques GODECHOT, La Grande nation. L'expansion révolutionnaire de la France dans le monde de 1789 à 1799, $2^{\mathrm{d}}$ edition, Paris Flammarion, 1983 ; Manuela ALBERTONE, Antonino DE FRANCESCO, Rethinking the Atlantic World: Europe and America in the Age of Democratic Revolutions, Ithaca, Palgrave Macmillan, 2009; David ARMITAGE, Sanjay SubRAHMANYAm (ed.), The Age of Revolutions in Global Context, c. 1760-1840, New Nork, Palgrave Macmilan, 2010 ; Suzanne DESAN, Lynn HUNT, William Max NELSON (ed.), The French Revolution in Global Perspective, Ithaca, Cornell University Press, 2013; Janet POLASKY, Revolutions Without Borders: The Call to Liberty in the Atlantic World, Yale, Yale University Press, 2015 ; Michael A. MCDONNELL (ed.), Rethinking the Age of Revolution, Atlantic Studies/ Global Currents, vol. 13, n 3, 2016.

17. Vanessa MONGEY, «Les Vagabonds de la République: les révolutionnaires européens aux Amériques, 1780-1820 ", in Federica MORELLI, Clément THIBAUD, Geneviève Verdo (eds), Les Empires atlantiques des Lumières au libéralisme (1763-1865), Rennes, Presses universitaires de Rennes, 2009, p. 67-82.

18. Jean-Pierre DEDIEU, «Les grandes bases de données. Une nouvelle approche de l'histoire sociale. Le système Fichoz », Revista da Faculdade de Letras Historia, 2005, vol. 3, n 5, p. 99-112, halshs-00004690 ; Jean-Pierre Dedieu et Álvaro Chaparro, «De la base au réseau. L'apport des bases de données à l'étude des réseaux ", Les Cahiers de Framespa [online], n 12, 2013, DOI : https://doi.org/10.4000/framespa.2173. My heartfelt gratitude goes to Andoni Artola Renedo who initiated me to the Fichoz database as well as to Pajek. 
19. Pierre SERNA, « Le Directoire, miroir de quelle république ? » in Pierre Serna (ed.), Républiques sœurs. Le Directoire et la Révolution atlantique, Rennes, Presses universitaires de Rennes, 2009, p. 7-20.

20. On the concept of revolutionary synergy: Joanna INNES, Mark PHILP (ed.), Re-Imagining Democracy in the Age of Revolutions: America, France, Britain, Ireland, 1750-1850, Oxford, Oxford University Press, 2013. On transnational circulations, several works were a direct inspiration: David V. ERDMAN, Commerce des Lumières. John Oswald and the British in Paris, 1790-1793, Columbia, University of Missouri Press, 1986; Michael DUREY, Transatlantic Radicals and the Early American Republic, Lawrence, University Press of Kansas, 1997 ; David A. WILSON, United Irishmen, United States. Immigrant Radicals in the Early Republic, Ithaca, Cornell University Press, 1998; Sylvie Kleinman, Translation, the French language and the United Irishmen (1792-1804), PhD dissertation, Dublin City University, 2005 ; Rachel ROGERS, Vectors of Revolution: The British Radical Community in Early Republican Paris, 1792-1794, PhD dissertation, Toulouse-Le Mirail University, 2012.

21. Clément THIBAUD, Républiques en armes. Les armées de Bolívar dans les guerres d'indépendance du Venezuela et de la Colombie, Rennes, Presses universitaires de Rennes, 2006.

22. Jacques LÉVY, «La mondialisation, un évènement géographique ", L'Information géographique, $\mathrm{n}^{\circ}$ 2, 2007, p. 6-31 (p. 29); Matthias MIDDELL et Katja NAUMANN, «Global History and the Spatial Turn: from the Impact of Area Studies to the Study of Critical Junctures of Globalization », Journal of Global History, n 5, 2010, p. 149-170.

23. Guy BEINER, Forgetful Remembrance: Social Forgetting and Vernacular Historiography of a Rebellion in Ulster, Oxford, Oxford University Press, 2018.

24. Theobald Wolfe Tone à Thomas Russell, 9 July 1791, in Theodore W. MoodY, Robert B. MCDOWELL, Christopher J. WOoDs (ed.), The Writings of Theobald Wolfe Tone, 1763-1798, 3 vol. , Oxford, Clarendon Press, 1998, 2001 et 2007, vol. I, p. 105.

25. [Thomas Paine], «Projet d'expédition en Irlande », [décembre 1792-janvier 1793], Service historique de la Défense, Vincennes, 1M1420, p. 28.

26. Sur le décret du 19 Novembre : Virginie MARTIN, «Le remodelage de l'espace international : le "décret de propagande" du 19 novembre 1792 ", communication dans le cadre du Colloque international «La loi en Révolution 1789-1795. Fonder l'ordre et établir la norme », 12-14 septembre 2013. Je remercie Virginie Martin qui m'a communiqué son texte.

27. The historiographical foundations for this section were mainly Albert MATHIEZ, La Révolution et les étrangers. Cosmopolitisme et défense nationale, Paris, La Renaissance du livre, 1918 ; Sophie WAHNICH, L'Impossible citoyen. L'étranger dans le discours de la Révolution française, Paris, Albin Michel, 1997; Michael Rapport, Nationality and Citizenship in Revolutionary France: The Treatment of Foreigners, 1789-1799, Oxford, Oxford University Press, 2000 ; Anne SIMONIN, Le Déshonneur dans la République. Une histoire de l'indignité 1791-1958, Paris, Grasset, 2008.

28. See Niklas fRYKMAN, The Bloody Flag. Mutiny in the Age of the Atlantic Revolution, Oakland, University of California Press, 2020.

29. Guy BEINER, « Probing the Boundaries of Irish Memory: from Postmemory to Prememory and Back », Irish Historical Studies, vol. 39, n 154, nov. 2014, p. 296-307.

30. Michel Foucault, "Des espaces autres. Hétérotopies", Conférence au Cercle d'études architecturales, 14 mars 1967, publié dans Architecture, Mouvement, Continuité, nº 5, 1984, p. 46-49. 


\section{AUTHOR}

\section{MATHIEU FERRADOU}

TEMOS

Le Mans Université 